\title{
The idea of humanism and socio-cultural bases of leges permissivae of Russian labor law
}

\author{
Alexey Lada ${ }^{1 *}$, and Sergey Markov \\ ${ }^{1}$ Far Eastern Institute of Management - RANEPA branch, 680000, Khabarovsk, Russia \\ ${ }^{2}$ Far Eastern State Medical University, 680000, Khabarovsk, Russia
}

\begin{abstract}
The philosophy of labor law in Russia is only being formed. This is evidenced by only a few philosophical studies on certain aspects of labor law, and the task is to create a new paradigm of Russian labor law on the basis of the ideals of humanism and Enlightenment in order to harmonize it with international labor law standards. The new metaphysics is the overcoming of Cartesian (ontological) dualism in labor law, represented by the counter-narrativeness of the employee and employer, as well as the dominance of its subjects (in particular, this concerns gender prohibitive norms). Thanks to the new metaphysics and its methods, the philosophy of labor law goes beyond the limits of objectivity to the existing (being) of modern labor relations. In their studies, the authors show the influence of philosophical (metaphysical) ideas on the creation and development of the "permissible" (leges permissivae) of Russian labor law. In particular, the studies propose an interpretation of the metaphysical (subjective law) and applied value of the labor law principles on examples of the philosophical moral and legal ideas implementation in the norms of labor law and in the further creation of a leges permissivae policy of labor law.
\end{abstract}

\section{Introduction}

A.V. Koyre (1892 - 1964) - Russian, French and American historian of science, in his famous article "On the influence of philosophical concepts on the development of scientific theories" (1954) convincingly proved the influence of philosophy (metaphysics) on the fundamental aspects (principles) of modern science. Starting with Etudes on Galileo (1939), he investigated and demonstrated to the general public the influence of metaphysical ideas on micro-revolution in science (natural science). In our work, we would like to demonstrate the influence of not only speculative (philosophical), but also applied ideas on the microevolution of the basic principles of Russian labor law, guided by the internalist provisions of Alexander Koyre and his school (Lakatos, Kun, Tulmin, Foucault, etc.), which Coire called the "metaphysical substructures" of thought, or, we put it, innovative ideas.

We will show the applied influence through the influence of humanistic ideas (human rights in the generally accepted sense), i.e. "Born-in, necessary rights belonging to

*Corresponding author: alexlada@inbox.ru 
humanity and inalienable rights" (Kant), to the emergence and development of permissible norms and duties in modern Russian labor law.

The specificity of the labor law philosophy consists in its focus on the provision of natural labor rights (subjective), especially of the employee. One of the goals of the labor law philosophy is the development and justification of such a procedure for regulating labor and related relations in which the moral and legal ideas of freedom, formal equality, justice and humanism permeate these relations. The modern philosophy of labor law is designed not only to evaluate the current labor legislation, but also to put forward proposals for its improvement in the spirit of the above philosophical and legal ideas. In the future, as the philosophy of labor law develops, the task of justifying the labor legislation reform may move into the area of "permissible" labor law policies, which is also currently at the stage of origin.

\section{Metaphysics and ideas of humanism}

As a result of studies of publications in the field of labor law, we have the impression that modern Russian labor law is based on the methodological paradigm of Aristotle-Newton, in the best case of Feuerbach and Marx, for various reasons, objective and subjective. The role of facts and experience, as well as the classical model of thinking, in science is not denied. Of course, this also applies to labor law. So, in the XX century it was considered a legal dogma that an employee performs work under the employer control, subject to the rules of the internal labor schedule. Chapter 49.1 of the Labor Code of the Russian Federation (hereinafter the Labor Code of the Russian Federation) introduced a new category of workers - remote workers (in philosophical language, changed the Aristotelian understanding of time and space). Their workplace and time are not literally under the control of the employer, they determine their work and leisure regimes by themselves, and they conclude an employment contract by exchanging electronic documents via the Internet. Remote work (labor) and an employee in remote access mode are becoming normal practice today.

Completely new relationships in the social and labor sphere make us turn to metaphysics (philosophy of law). This must be done, if only in order to reinterpret the numerous phenomena and facts that have accumulated in the labor legislation that await their Alexander Koyre, but only in the field of labor law. In other words, the events and facts accumulated in dissertations and monographs urgently require internalist, as well as metaphysical, rethinking and analytical analysis.

At the beginning of the XXI century, metaphysics is reborn again, but already as a new metaphysics of science and humanism. Dean of the Faculty of Philosophy, Moscow State University, Professor V.V. Mironov in his article "Metaphysics does not die (Heidegger and his defense of metaphysics)", referring to A.L. Dobrokhotova, N.V. Motroshilov, F.I. Girenka, H. Hofmeister, K. Jaspers (Jaspers K., 1957, 1971), notes that today we see a return to metaphysics in the format of combining ontology, epistemology, ethics, anthropology. According to V.V. Mironov, metaphysics is the essence of philosophy initially, and is further formed as a special way of philosophical (speculative) reflection beyond the limits of experimental knowledge with the aim of answering the main questions of being. The methods of metaphysics are reflection and self-reflection, criticism and selfcriticism, doubt of the [transcendental] being. Metaphysics is what distinguishes philosophy from classical science. In other words, metaphysics (that which is beyond the boundaries of "physics") is a speculative doctrine of being and morality, or "metaphysics is a special type of ultimate comprehension of being" (Mironov, p. 85).

Despite its clear criticism, metaphysical reflection also resorts to modern sociology, for example, as part of the Latour-Collins Alternative Science and Technology Research 
Project. In his actor-network theory, Bruno Latour first criticizes it in the famous article "Philosophical self-disclosure" (2010), and then returns to the methods (more precisely: the language) of metaphysics (ontology) (Latour, 2010).

It seems to us that contemporary Russian labor law is lacking self-reflection and criticism and a return to the ideals of Enlightenment and humanism. For example, from the content of one of the labor law principles specified in Article 2 of the Labor Code of the Russian Federation, it follows that wages above the living wage are worthy for him and his family. Given that the size of the living wage in the Russian Federation in 2019 is approximately $\$ 200$ US, it is obvious that in this case we can only talk about a salary that ensures the survival of the employee, and not his worthy existence. Another example is the discrimination of men with family responsibilities that has persisted since Soviet times. Article 258 of the Labor Code of the Russian Federation provides for the provision of breaks for feeding a child only to the mother of the child, and a single father raising a child does not have such a right. The authors also pay attention to legislation that discriminates against women. In particular, it should be agreed with N. Lyutov that the list of professions prohibited for Russian women goes beyond the protection of women's reproductive health and widely limits their access to professions and, therefore, should be changed to avoid discrimination (Lyutov, 2016, p. 35). The above examples show the deviation of Russian labor law from the principles of humanism and equality. The appeal to the ideas of humanism in the sociology of law is not a regression, but a step beyond its empirical facts.

In this regard, it makes sense to turn to methodological research and the results of a joint scientific project S.M. Markov and professors of the Pontifical Catholic University of Argentina (UCA) Viviana Yaccuzzi Polisena "Metaphysics as a phenomenon of modern humanism: a methodological aspect" (Khabarovsk, 2018). For us, these are important methodological tips that can be applied to the philosophical analysis of labor law (Markov and Yakuzi, 2018).

The project proposes a new concept of metaphysics as a phenomenon of modern humanism (anthropology) in a modern interpretation. Russian and Argentine philosophers propose to get rid of the patterns of isolated thinking generated by scientism and technological progress, and return to the ideals of Enlightenment and humanism. It seems to us that modern Russian labor law also suffers from the disease of "isolated thinking generated by scientism" in jurisprudence. According to Art.91 of the Labor Code of the Russian Federation, the working week in the Russian Federation is 40 hours, despite the fact that in many foreign countries there has long been a tendency to reduce working hours to 30 hours a week in order to provide employees with more free time for sports, health, and spiritual development.

In his work S.M. Markov and Viviana Yaccuzzi (Viviana Yaccuzzi Polisena) for the first time put into scientific circulation a new definition of man - cogito complexus. It seems to us that the cogito complexus provides not only a completely new perspective on the life of people in society, ensuring the inner harmony of each person, which in turn favorably improves the life of all mankind, but will allow us to look at the fundamental principles of labor law through metaphysical reflection and self-criticism. Cogito complexus is a socially responsible person, acting, rational, intelligent, sensual, bioethical in society, which means in the field of labor relations. Cogito complexus is a universal person (capable of any type of activity), holistic (integrating the physical, mental and spiritual principles), unique (open to the world, unrepeatable, spiritually incomplete). The doctrine of cogito complexus is a branch of metaphysics grafted to the tree of humanism and the ideals of the Enlightenment. The new science of man (cogito complexus) is metaphysics and anthropology of the XXI century. In Russia, it is represented by Dr. of Phys. sciences, professor of Moscow State University Y.S. Vladimirov, the scientific 
journal "Metaphysics" of the RUDN University (Moscow), as well as the scientists of the philosophical faculty of Moscow State University (MSU).

In addition to the indicated direction, in modern science, as the opposite, a purely scientific direction took shape, formed in the 20-30s of the XX century, thanks to the activities of the Vienna Circle (M. Schlick, L. Wittgenstein, R. Karnap, H. Reichenbach, John von Neumann et al.). Scientists of the Vienna Circle created a standard concept of science and developed fundamental criteria for separating scientific knowledge from philosophical, unscientific, everyday and pseudoscience.

In the philosophy of science, the main approaches to the study of science gradually emerged: metaphysical, logical-epistemological, sociological, socio-ultural, etc. As a result, we received two solutions to the problem: fundamental and applied. It seems to us that in the field of criticism and self-reflection of the fundamental principles of Russian labor law, these two areas do not exclude but complement each other, as they said earlier, are dialectically interconnected. The metaphysical status of modern labor law criticism is metaphysics (ontology, epistemology, ethics, anthropology), applied - logic, hermeneutics, legal anthropology and sociology.

Being (including the essence of labor law) is known by the method of metaphysics, or add speculation, as M. Mamardashvili considered in his lectures. Thanks to metaphysical reflection, we can go beyond the limits of objectivity to existing (being). Otherwise, philosophy turns into science (natural science) or school philosophy, at best, as Alexander Koyre said, in the "cemetery of forgotten theories". Metaphysics, according to V.V. Mironov, A.L. Dobrokhotov, N.V. Motroshilova, F.I. Girenok, Y.S. Vladimirov, S.M. Markov, H. Hofmeister, Bruno Latour, Viviana Yakusi, today is in demand as the ultimate (transcendental) way of understanding the modern problems of human life and the essential characteristics of modern science.

An example is the philosophical and legal research of a professor from the Institute of Philosophy and Law of the Siberian Branch of the RAS N.S. Rozova "The principle of human protection (anthroprostasia) and current value conflicts." In the philosophical and anthropological principle of anthroprostasy, the legal philosopher conducts substantiation and protection through metaphysical dilemmas of the generally significant (basic) sociocultural values of a person and the right to dignity, freedom and meaningfulness is more substantial (Rozov, 2019). Anthroprostasia harmoniously complements cogito complexus. Section 2 "Social partnership in the world of work" can serve as an example of this principle in the Labor Code of the Russian Federation. Obviously, the interests of workers and the employer are opposite. In this regard, the labor theory scientists point to the need to find the optimal balance of interests in labor law (Ivanova, 2018). As noted in the labor law science, in order to balance the interests of workers and the employer, there is a need for an active socially-oriented policy in which government and local governments must actively intervene in any major collective labor conflict in order to prevent its escalation and spread (Zaitseva et al. , 2019, p. 55).

\section{Leges permissivae labor law}

The study of metaphysics (ontology) of labor law was dealt with by A.K. Bezina, J.V. Shchelyvanova D.A. Safina, N.G. Shigapov, A.M. Lushnikov, M.V. Lushnikova and others. It should be emphasized that today several schools have been formed in Russia: Moscow, St. Petersburg, Ural, Siberian, Tomsk, Yaroslavl, and Omsk. As a result of comprehensive studies, certain results were achieved: unconventional approaches to the study of legal facts in labor law were developed, the concept of a "labor transaction" was formulated, the place of labor rights in the human rights system was studied, as well as foreign experience with the aim of creating a new national model of legal regulation of 
labor et al. (Lushnikov and Lushnikova, 2017, p. 15). But most importantly, legal scholars have justified the emergence of new institutions and sub-institutes of labor law, for example, information labor law and distance labor, conflict of labor law. As a result, labor law has reached an interdisciplinary level. But, unfortunately, it never reached the philosophical status, the philosophy of labor law did not form in Russian scientific schools.

Human rights and liberty in the generally accepted sense of them are a sacred institution of liberal and democratic civilizations, enshrined in Constitutions and Declarations. A striking example is the contract law of Locke, Hobbes, Kant. They act as the pactum sociale of applied law, of course, if these generally accepted norms are not declarative in nature, but a mandatory imperative for the authorities.

"Metaphysics," S.M. Markov and Viviana Yakuzi, as a modern science [worldview] suggests that we think about creating new hypotheses [about man and the cosmos] in order to return to the ideals of the Enlightenment in order to create a new type of worldview [thinking]. The new metaphysical thinking [worldview] with bioethical content will contribute, as we see it, to the development of new principles and formalisms of cogito complexus (Markov and Yakuzi, 2018, p. 67). Modern science has become positivism without a humanitarian methodology. Overcoming the current crisis is possible only through the revival of humanism in science, for example, in the format of metaphysics and its methods. However, we do not fundamentally (especially in the sociology of labor law) oppose the periodic table of STS Collins-Evans experiments.

According to Professor Andrew Pickering, we live in a technologically transformed world in which space and time are perceived on their own in the context of the ontological dualism of Descartes and Mondrian. In the article "New Ontologies", he notes that "we must resist the ontology of dualism and domination" by Descartes-Mondrian (Pickering, 2017, p.163) through criticism and self-reflection and turn to the de Kooning ontology (Pickering, 2017, p. 163-164). And this is not only about painting (Pickering, 2017, p. 161). In the classical philosophy of labor law, we also observe the dualism of the employee and the employer, reinforced by the dualistic separation and dominance of its subjects. The new labor law policy leges permissivae proposes a new subject - the cogito complexus, which will fill the world of labor law with "consciously decentralized practices" (Pickering) and new metaphysics, eliminate the dualism of its subjects through the "permissible principles" of labor relations. "If dualistic separation and domination is still our natural ontological attitude," says Pickering, "it is because since the industrial revolution we have transformed the material world to make them such an attitude" (Pickering, 2017, p.168). In the concept of permissible law, the symmetrical (equal) interaction of the employee and the employer is highlighted.

\section{Conclusion}

The ideals of humanism and Enlightenment allow (at the level of legislation) moving from prohibitive-restrictive labor law to permissible (in our context, humanitarian) in the field of labor relations. In short, microevolution can be expressed by the formula: "Everything is permitted except those prohibited by law." This is how we understand the policy of leges permissivae of modern Russian labor law, in which the cogito complexus, free and voluntarily limited in its labor rights, should act as a subject. Of course, we are not talking about absolute (anarchist) freedom. Norms remain, but they turn into generally binding norms (legal) within the framework of universal contract labor law with the addition of labor ethics and corporate law (etiquette). So the contractual regulation of relations in labor law is limited by the ban on worsening the situation of workers in comparison with the current legislation (Article 9 of the Labor Code of the Russian Federation). 
The appeal to the metaphysical aspects of legal philosophy is associated with the need for a broader approach to the consideration of controversial and problematic issues of history and trends in the modern development of Russian labor law, as well as selfreflection of value conflicts (disputes). Unfortunately, in labor law the permissible type of legal regulation based on the equality of parties is applied only in the contractual regulation of social and labor relations. In other cases, the employer has economic power in relation to the employee, under which he unilaterally creates new responsibilities for the employee.

\section{References}

1. Y.V. Ivanova, Search for the optimal balance of interests in labor law, Labor law in Russia and abroad. 3, 29-31 (2018).

2. A.M. Lushnikov, M.V. Lushnikova, Ontology of the domestic science of labor law in the post-Soviet period (Monograph, Moscow, 2017).

3. S.M. Markov, V. Yakuzi, Metaphysics as a phenomenon of modern humanism: methodological aspect, DIXI - 2018: ideas, hypotheses, discoveries in social and humanitarian research: collection of scientific works: issue 9, under ed. of Doctor of Soc. Sciences A. Y. Zavalishina, Khabarovsk, 57-78 (2018).

4. V.V. Mironov, Metaphysics does not die (Heidegger and his defense of metaphysics). Intelligence. Innovation Investments, Intelligence. Innovations. Investment, 9, 84-97 (2017)

5. E. Pickering, New ontologies, Logos, 27 (3), 154-172 (2017).

6. N.S. Rozov, The principle of human protection (anthroprostasia) and relevant value conflicts, Human, 30 (2), 176-190 (2019).

7. B. Latour, Coming Out as a Philosopher, Social Studies of Science, 40 (4), 599-608 (2010).

8. N. Lyutov, Russian law on discrimination in employment: can it be compatible with international labor standards?, Russian Law Journal, IV (3), 7-50 (2016)

9. L. Zaitseva, E. Gomes, S. Racheva, \& V. Cruz, Intermediary in a collective labor dispute resolution, BRICS Law Journal, VI (2), 33-59 (2019). 